\title{
Hydrolyzed collagen (gelatin) decreases food efficiency and the bioavailability of high-quality protein in rats
}

\author{
Colágeno hidrolisado (gelatina) reduz a \\ eficiência alimentar e a biodisponibilidade \\ de proteina de alta qualidade em ratos
}

Cláudia Cantelli Daud BORDIN ${ }^{1}$

Maria Margareth Veloso NAVES'

\section{A B S T R A C T}

\section{Objective}

Although deficient in all indispensable amino acids, gelatin is used in protein-restricted diets. Food efficiency and protein quality of casein and gelatin mixtures in low protein diets in Wistar rats were investigated.

\section{Methods}

The rats were treated with protein-restricted diets (10.0 and 12.5\%) containing casein (control diets), casein with gelatin mixtures (4:1 of protein content), and gelatin as sources of protein. The food conversion ratio, protein efficiency ratio, relative and corrected protein efficiency ratio, true protein digestibility, and hepatic parameters were estimated.

\section{Results}

After 28 days of the experiment, food efficiency of $10.0 \%$ casein/gelatin diet decreased when compared to that of $10.0 \%$ casein diet, and the protein efficiency ratio of the casein/gelatin mixtures $(10.0 \%=2.41$ and $12.5 \%=2.03)$ were lower than those of the casein $(10.0 \%=2.90$ and $12.5 \%=2.32)$. After 42 days of the experiment, the weight of the liver of the animals treated with 10.0 and $12.5 \%$ casein/gelatin diets, and the liver protein retention of the $12.5 \%$ casein/gelatin diet group of animals were lower than those of the control group.

\section{Conclusion}

Gelatin decreases food efficiency and high-quality protein bioavailability in protein-restricted diets.

Keywords: Amino acids. Biological availability. Caseins. Gelatin. Proteins. Rats.

\footnotetext{
1 Universidade Federal de Goiás, Faculdade de Nutrição, Programa de Pós-Graduação em Nutrição e Saúde. R. 227, Qd. 68, 74605-080, Goiânia, GO, Brasil. Correspondência para/Correspondence to: MMV NAVES. E-mail: <mmvnaves@gmail.com>. Support: Conselho Nacional de Desenvolvimento Científico e Tecnológico.
} 


\section{R E S U M O}

\section{Objetivo}

A gelatina é deficiente em todos os aminoácidos indispensáveis, mas é usada em dietas com restrição de proteína. A eficiência alimentar e a qualidade da proteína de misturas de caseína com gelatina em dietas com baixo teor de proteína foram investigadas em ratos Wistar.

\section{Métodos}

Ratos foram tratados com dietas restritas em proteína (10,0 e 12,5\%), contendo, como fonte de proteína: caseína (dieta controle), misturas de caseína com gelatina (4:1 do teor de proteína) e gelatina. Foram estimados os seguintes índices: taxa de conversão alimentar, quociente de eficiência proteica, quociente de eficiência proteica relativo e corrigido, digestibilidade verdadeira da proteína e parâmetros hepáticos.

\section{Resultados}

Após 28 dias de experimento, a eficiência alimentar da dieta caseína:gelatina a 10,0\% diminuiu em comparação com a dieta de caseína a 10,0\%, e o quociente de eficiência proteica das misturas caseína: gelatina $(10,0 \%=2,41$ e 12,5\%=2,03) foi menor do que aqueles da caseína $(10,0 \%=2,90$ e 12,5\%=2,32). Após 42 dias de experimento, o peso do fígado dos animais tratados com mistura caseína:gelatina a 10,0 e 12,5\% e a retenção proteica no fígado dos animais do grupo caseína: gelatina a 12,5\% diminuíram em comparação ao grupo-controle.

\section{Conclusão}

Gelatina reduz a eficiência alimentar e a biodisponibilidade de proteína de alta qualidade em dietas restritas em proteínas.

Palavras-chave: Aminoácidos. Disponibilidade biológica. Caseínas. Gelatina. Proteínas. Ratos.

\section{NTRODUCTION}

Gelatin is a soluble mixture of polypeptides produced by the partial hydrolysis of collagen?. Collagen is an insoluble protein of animal origin that holds organs and tissues together and gives strength to tendons, among other biological functions ${ }^{2,3}$. In nutritional terms, gelatin is an incomplete protein because its amino acid profile is quite atypical and deficient in all of the indispensable (essential) amino acids recommended by the Food and Nutrition Board of the Institute of Medicine (IOM) of the National Academy of Sciences ${ }^{4}$. It is known that gelatin contains no tryptophan ${ }^{5,6}$.

Gelatin and collagen hydrolysate have been shown to improve skin hydration, transepidermal water loss, elasticity, and skin barrier dysfunction ${ }^{7,8}$. Furthermore, they have been used to promote weight loss because studies have shown that gelatin can inhibit appetite and promote satiety ${ }^{9,10}$. However, the use of gelatin in a protein-restricted diets (like those before and after gastrointestinal tract surgery, chronic renal insufficiency treatment diets, and those aimed to promote weight loss ${ }^{11,12}$ ) could be a potential nutritional risk. Insufficient protein intake (in terms of both quantity and quality) inhibits endogenous metabolism of proteins, prolongs the inflammatory phase of the healing process, decreases fibroblast proliferation, angiogenesis and collagen synthesis, and impairs tissue repair ${ }^{12}$. Therefore, the use of gelatin in a protein-deficient diet could slow patient recovery.

Considering the uses of gelatin in proteinrestricted diets, this study investigated food efficiency and protein quality of casein (a complete protein) and gelatin mixtures in low protein diets administered to Wistar rats.

\section{METHODS}

The biological assay was carried out with 36 weanling male Wistar rats (21-23 days old), which were randomically distributed in six groups with six animals each, and average body weight ranging from 51.8 to $54.6 \mathrm{~g}$ per group. The rats were kept in individual cages and under standard 
environmental conditions (12-h light/dark cycle, relative humidity between $40-70 \%$, temperature between $\left.20-23^{\circ} \mathrm{C}\right)^{13}$. The rats were fed diets formulated according to the American Institute of Nutrition (AIN-93G) ${ }^{14}$ (Table 1), containing different sources of protein and reduced protein contents, as follows: $\mathrm{C}_{10}-10.0 \%$ protein (casein); $\mathrm{C}_{8} \mathrm{G}_{2}-10.0 \%$ protein $(8.0 \%$ casein and $2.0 \%$ gelatin); $C_{12.5}-12.5 \%$ protein (casein); $C_{10} G_{2.5}-12.5 \%$ protein ( $10.0 \%$ casein and $2.5 \%$ gelatin); $G_{10}-10.0 \%$ protein (gelatin), and protein-free diet. In the $\mathrm{C}_{8} \mathrm{G}_{2}$ and $C_{10} G_{2.5}$ diets, $20.0 \%$ of casein protein was replaced with gelatin protein (4:1 of protein content) to simulate the proportion of gelatin in a protein-restricted diet, besides the protein complementation $\left(\mathrm{C}_{8} \mathrm{G}_{2}\right)$ and supplementation $\left(\mathrm{C}_{10} \mathrm{G}_{2.5}\right)$ when compared to the $\mathrm{C}_{10}$ diet (control). The protein content in the diets ranged from approximately $0.0 \%$ (protein free) to $10.0 \%\left(C_{10}\right.$. $\mathrm{C}_{8} \mathrm{G}_{2}$ and $\left.\mathrm{G}_{10}\right)$ and $12.5 \%\left(\mathrm{C}_{12.5}\right.$ and $\left.\mathrm{C}_{10} \mathrm{G}_{2.5}\right)$, and all protein diets had similar energy values, which were estimated using the conversion factors of 4,4 , and $9 \mathrm{kcal} / \mathrm{g}$ for protein, carbohydrates and lipids, respectively ${ }^{15}$ (Table 1). Food and water (filtered) were provided to the animals ad libitum for 45 days, comprising 3 days of acclimatization and the following experimental periods: 2 weeks for the protein-free and $\mathrm{G}_{10}$ groups and 4 weeks for the $C_{10}, C_{8} G_{2}, C_{12.5}$ and $C_{10} G_{2.5}$ groups. The treatment of the protein-free and $\mathrm{G}_{10}$ groups was maintained for two weeks only to avoid animal suffering since they showed severe weight loss. In order to evaluate the influence of complementation and supplementation combining casein and gelatin on the growth of the animals and the liver protein retention, the treatment of the $C_{10}, C_{8} G_{2}$ and $C_{10} G_{2.5}$ groups were maintained for 2 more weeks (total: 6 weeks). Food intake was monitored daily, and the acceptance of each diet was assessed comparing the amount of food consumed versus the amount of food offered. The animals were weighed three times a week. For the analysis of protein content, the animal feces were collected over 7 days during the second (for the protein-free and $G_{10}$ groups) or the fourth week (for other groups) of the experiment. The

Table 1. Ingredients and proximate composition of experimental diets with different contents and sources of protein.

\begin{tabular}{|c|c|c|c|c|c|c|}
\hline \multirow{2}{*}{ Component } & \multicolumn{6}{|c|}{ Diet } \\
\hline & Protein-Free & $\mathrm{G}_{10}$ & $C_{10}$ & $\mathrm{C}_{8} \mathrm{G}_{2}$ & $C_{12}$ & $\mathrm{C}_{10} \mathrm{G}_{2.5}$ \\
\hline \multicolumn{7}{|l|}{ Ingredient (g/100 g) } \\
\hline Casein & - & - & 11.0 & 8.8 & 13.7 & 11.0 \\
\hline Gelatin & - & 11.4 & - & 2.3 & - & 2.8 \\
\hline L-cystine & - & - & 0.2 & 0.1 & 0.2 & 0.2 \\
\hline Soybean oil & 7.0 & 7.0 & 6.7 & 6.8 & 6.6 & 6.7 \\
\hline Cellulose & 5.0 & 5.0 & 5.0 & 5.0 & 5.0 & 5.0 \\
\hline Mineral mix & 3.5 & 3.5 & 3.5 & 3.5 & 3.5 & 3.5 \\
\hline Vitamin mix & 1.0 & 1.0 & 1.0 & 1.0 & 1.0 & 1.0 \\
\hline Choline bitartrate & 0.3 & 0.3 & 0.3 & 0.3 & 0.3 & 0.3 \\
\hline Corn starch & 83.2 & 71.8 & 72.4 & 72.2 & 69.6 & 69.7 \\
\hline \multicolumn{7}{|c|}{ Proximate composition ( $\mathrm{g} / 100 \mathrm{~g})$} \\
\hline Moisture & 10.4 & 10.4 & 9.8 & 8.8 & 9.9 & 9.9 \\
\hline Protein & 0.2 & 10.8 & 10.3 & 10.7 & 12.8 & 12.8 \\
\hline Lipids & 6.2 & 6.3 & 7.0 & 7.0 & 7.0 & 7.1 \\
\hline Total carbohydrates & 81.1 & 70.3 & 70.6 & 70.2 & 68.0 & 68.1 \\
\hline Ash & 2.1 & 2.1 & 2.3 & 2.3 & 2.3 & 2.2 \\
\hline Energy value (kcal) & 308.8 & 381.4 & 386.7 & 386.4 & 386.4 & 387.6 \\
\hline
\end{tabular}

Note: PF: Protein-Free, $G_{10}: 10.0 \%$ protein (gelatin), $C_{10}: 10.0 \%$ protein (casein), $C_{8} G_{2}: 10.0 \%$ protein (8.0\% casein and $2 \%$ gelatin), $C_{12.5}: 12.5 \%$ protein (casein), and $C_{10} G_{2.5}: 12.5 \%$ protein (10.0\% casein and $2.5 \%$ gelatin). Formulation according to AlN-93G ${ }^{14}$. Casein: $91.1 \% \pm 0.29$ of protein and $2.9 \% \pm 0.21$ of lipids, gelatin: $88.0 \% \pm 0.63$ of protein and $0.1 \% \pm 0.01$ of lipids. L-cystine: $0.3 \mathrm{~g}$ for each $20 \mathrm{~g}$ of casein. Values are means of three replicates, with the exception of total carbohydrates, estimated by difference. 
liver of $\mathrm{C}_{10}, \mathrm{C}_{8} \mathrm{G}_{2}$ and $\mathrm{C}_{10} \mathrm{G}_{2.5}$ groups was removed at the end of the sixth week. The experiment was carried out in accordance with the principles and procedures stated in the guide for the care and use of laboratory animals ${ }^{13}$, and it was approved by the Ethics Committee in Research of the Universidade Federal de Goiás (Protocol n 381/10).

The gelatin and casein amino acid contents were determined after hydrolysis of the protein in an acid solution using an amino acid analyzer (Nicolas V, Ribeirão Preto [SP], Brasil) and colorimetric post-column detection with ninhydrin ${ }^{16}$. The amino acid profile of a powdered, unflavored gelatin (a common brand sold in Brazilian markets) was also analyzed to ensure that the gelatin used in the experimental diets was similar to gelatin used for human consumption. The indispensable Amino Acid Score (AAS) was estimated using the amino acid analysis results, which were compared to the requirement pattern for indispensable amino acids proposed by the $\mathrm{IOM}^{4}$, as follows: AAS $=[$ (mg of amino acids in $1 \mathrm{~g}$ of protein test/ $\mathrm{mg}$ of amino acids in standard) $\times 100$ ]

The amino acid profiles of the gelatin used in the experimental diets and the commercial gelatin (for human consumption) were similar, which allows extrapolation of this study results to the gelatin commonly used for human consumption. There is no tryptophan in gelatin, and according to the requirement pattern, gelatin is also deficient in other indispensable amino acids ${ }^{4}$. The casein/gelatin mixture $(4: 1$ of protein content) meets the patterns of amino acid requirements (Table 2 ).

The Nitrogen ( $\mathrm{N}$ ) content of casein, gelatin, experimental diets, and rats' feces and liver were analyzed by the micro-Kjeldahl method using the factors 6.38 for casein, 5.55 for gelatin, and 6.25

Table 2. Amino acid composition of casein, gelatin, and Amino Acid Score (AAS) according to the Food and Nutrition Board/Institute of Medicine requirement pattern.

\begin{tabular}{|c|c|c|c|c|c|}
\hline $\begin{array}{l}\text { Amino Acid (mg of amino } \\
\mathrm{acid} / \mathrm{g} \text { protein) }\end{array}$ & Casein & $\begin{array}{c}\text { Gelatin } \\
\text { (used in diets) }\end{array}$ & $\begin{array}{l}\text { Commercial } \\
\text { gelatin }\end{array}$ & $\begin{array}{c}\text { Casein/gelatin } \\
\text { (4:1 of protein content) }\end{array}$ & $\begin{array}{c}\text { Requirement } \\
\text { pattern }\end{array}$ \\
\hline \multicolumn{6}{|l|}{ Indispensable (Essential) } \\
\hline Histidine & 28.8 & 11.1 & 12.3 & 25.3 & 18 \\
\hline Isoleucine & 38.2 & 15.1 & 16.4 & 33.6 & 25 \\
\hline Leucine & 90.6 & 30.4 & 32.8 & 78.6 & 55 \\
\hline Lysine & 82.7 & 47.7 & 43.6 & 75.7 & 51 \\
\hline Methionine + Cysteine & 32.7 & 10.6 & 8.4 & 28.3 & 25 \\
\hline Phenylalanine + Tyrosine & 104.8 & 30.7 & 39.6 & 90.0 & 47 \\
\hline Threonine & 45.1 & 16.9 & 14.5 & 39.5 & 27 \\
\hline Tryptophan & 16.1 & 0.0 & 0.0 & 12.9 & 7 \\
\hline Valine & 44.6 & 22.4 & 26.5 & 40.2 & 32 \\
\hline Total & 483.6 & 184.9 & 194.1 & 423.9 & 287 \\
\hline \multirow[t]{2}{*}{ AAS (\%) } & 130.8 & $0.0(\operatorname{Trp})$ & 0.0 (Trp) & 113.1 & 100 \\
\hline & (Methionine + Cysteine) & & & (Methionine + Cysteine) & \\
\hline \multicolumn{6}{|l|}{ Dispensable (Non-essential) } \\
\hline Aspragine & 91.0 & 58.4 & 62.5 & 84.48 & \\
\hline Glutamine & 181.7 & 96.4 & 108.6 & 164.64 & \\
\hline Alanine & 34.6 & 125.3 & 94.3 & 52.74 & \\
\hline Arginine & 36.6 & 97.2 & 87.8 & 48.72 & \\
\hline Glycine & 20.7 & 268.9 & 299.0 & 70.34 & \\
\hline Proline & 108.5 & 138.3 & 126.6 & 114.46 & \\
\hline Serine & 59.4 & 30.8 & 27.2 & 53.68 & \\
\hline Total & 532.5 & 815.1 & 806.0 & 589.02 & \\
\hline
\end{tabular}

Note: Casein/gelatin (4:1 of protein content): estimated value, not analyzed. Requirement pattern of indispensable amino acids for preschool

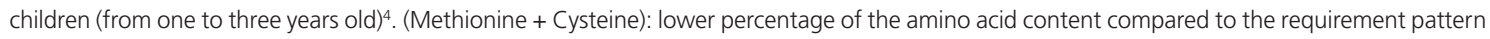
and (Tryptophan): limiting amino acid. 
for feces and liver for converting nitrogen to crude protein ${ }^{17}$. Lipid content of the diets and livers was analyzed according to the method described by Bligh \& Dyer ${ }^{18}$. Moisture and ash were analyzed using the methods defined by the Association of Official Analytical Chemists ${ }^{17}$, and the total carbohydrate content of the diets (including fiber) was calculated by subtracting the weight of total fat, crude protein, moisture, and ash from the total weight of the food.

\section{Food and protein efficiency evaluation}

The biological availability of the diets was evaluated using the following parameters: animals' growth and weight gain curve; Food Conversion Ratio (FCR), which represents the efficiency of food intake in promoting weight gain; Protein Efficiency Ratio (PER), which is based on body weight gain compared to protein intake over a period of four weeks; Relative Protein Efficiency Ratio (RPER); Corrected PER, which is estimated by the PER of the protein test adjusted for the value of 2.5 (standard value for casein PER, estimated in diets with $10 \%$ protein); and true protein digestibility, assessed as the difference between nitrogen intake and nitrogen absorbed (fecal nitrogen input) and was expressed as a percentage ${ }^{19,20}$. The hepatic profile of the $C_{10^{\prime}}$ $\mathrm{C}_{8} \mathrm{G}_{2}$ and $\mathrm{C}_{10} \mathrm{G}_{2.5}$ groups was evaluated by the liver weight (g), relative liver weight (g per $100 \mathrm{~g}$ of body weight), and protein and fat contents.

The results of the chemical and biological assays were expressed as mean and standard deviation, and the data were submitted to the Analysis of Variance (Anova) and Tukey's test, with

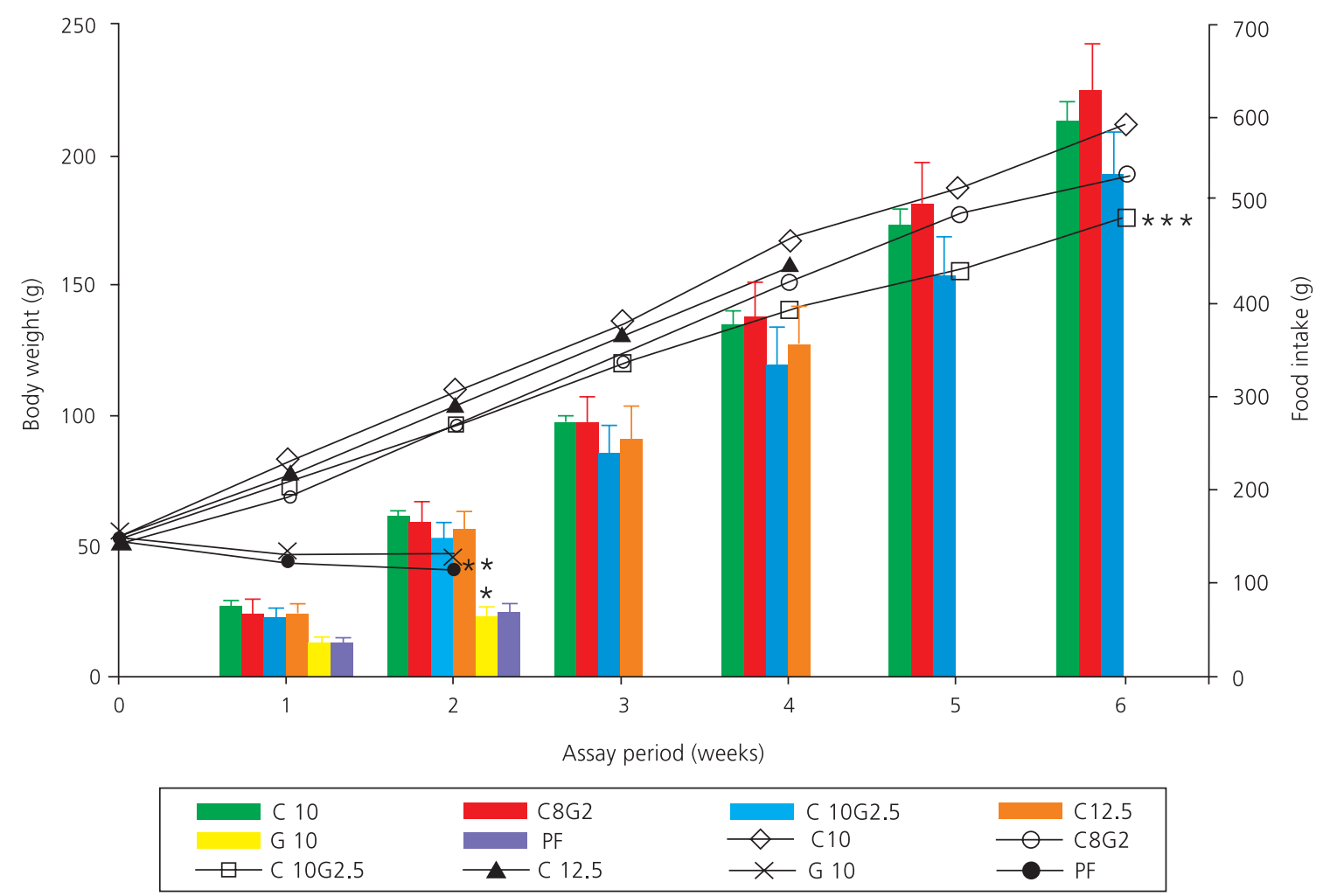

Figure 1. Body weight (lines) and food intake (bars) of rats treated with different diets over 6 weeks of experiment.

Note: $C_{10}-10.0 \%$ protein (casein), $C_{8} G_{2}-10.0 \%$ protein (8.0\% casein and $2.0 \%$ gelatin), $C_{10} G_{25}-12.5 \%$ protein $(10.0 \%$ casein and $2.5 \%$ gelatin), $C_{125}-12.5 \%$ protein (casein), $G_{10}-10.0 \%$ protein (gelatin), and Protein-Free (PF). After 2 weeks of experiment: *Significant differences in food intake between $G_{10}$ and $P F$ groups compared to the other groups; ** Significant differences in body weight between $G_{10}$ and $P F$ groups compared to the other groups. After 6 weeks of the experiment: ${ }^{* * *}$ Significant difference in body weight between $C_{10} G_{2.5}$ and $C_{10}$ groups $(p<0.05)$. 
significance level set at $p<0.05$ using the Statistica Software Stat Soft Inc., $7^{\text {th }}$ version (Tulsa, Oklahoma, United States, 2004).

\section{RE S U L T S}

The animals of the $C_{10}, C_{8} G_{2}, C_{10} G_{2.5}$, and $C_{12.5}$ groups had similar body weight at the fourth week of experiment ( $p>0.05$ ), and the $C_{10} G_{2.5}$ group had lower body weight gain than $C_{10}$ group at the sixth week $(p<0.05)$ (Figure 1$)$. The $G_{10}$ and protein-free groups showed similar weight loss ( $p>0.05)$ and low diet acceptance $\left(G_{10}=42.4 \%\right.$ \pm 6.4 and protein-free $=48.2 \% \pm 6.7$ ) during the feeding period when compared to the other groups after two weeks of experiment $\left(C_{10}=85.6 \% \pm 5.5, \quad C_{8} G_{2}=82.5 \% \quad \pm 11.8\right.$, $C_{10} G_{2.5}=81.9 \% \pm 11.2$ and $\left.C_{12.5}=73.4 \% \pm 9.6\right)$. Although weight gain and food intake of the protein diets were similar after four weeks of experiment (Figure 1), the FCR of the experimental groups were higher than that of the $10 \%$ protein control group in the protein complementation $\left(C_{8} G_{2}\right.$ versus $\left.C_{10}\right)$ and supplementation $\left(C_{10} G_{2.5}\right.$ versus $C_{10}$ ) diets (Table 3 ). After six weeks of experiment, the weight gain was similar in the protein complementation $\left(\mathrm{C}_{8} \mathrm{G}_{2}=141.6 \mathrm{~g} \pm 22.0\right)$ diet, but in the protein supplementation diet was lower in the experimental group $\left(C_{10} G_{2.5}=122.4 \mathrm{~g}\right.$ $\pm 15.5)$ than in the control group $\left(C_{10}=157.5 \mathrm{~g}\right.$ $\pm 19.8)(p<0.05)$.

The protein efficiency ratio of the diets with the casein/gelatin mixtures was lower than those of their respective controls $\left(C_{8} G_{2}\right.$ versus $C_{10}$ and $\mathrm{C}_{10} \mathrm{G}_{2.5}$ versus $\mathrm{C}_{12.5}$ ), as well as in the protein supplementation diet $\left(\mathrm{C}_{10} \mathrm{G}_{2.5}\right)$ compared to the $C_{10}$ diet. The corrected PER of the $C_{8} G_{2}$ diet was approximately 2.0 when adjusted to the standard value of casein PER. The True Protein Digestibility of the diets was approximately 95\% (Table 3).

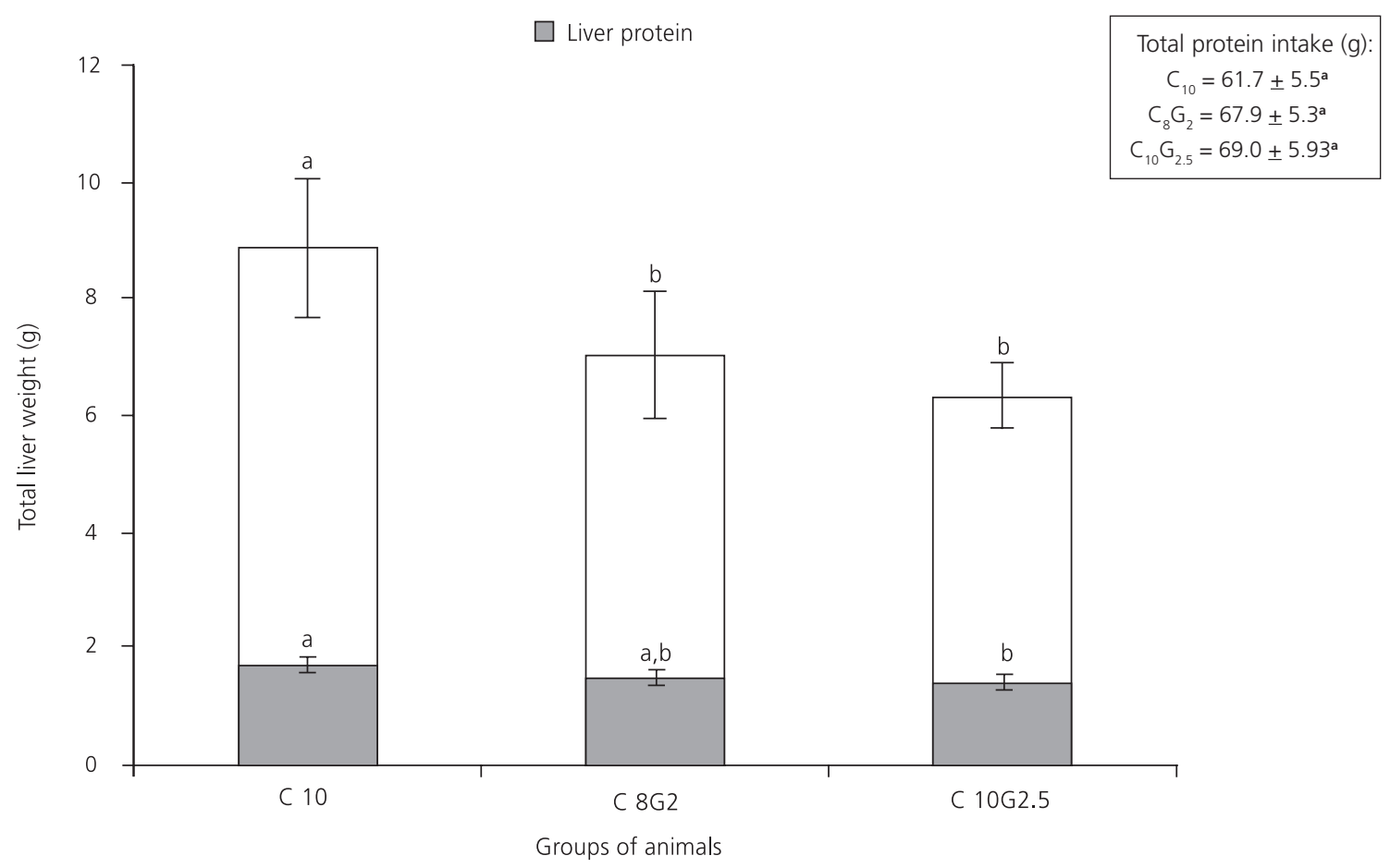

Figure 2. Total liver weight ( $\mathrm{g}$ ) and liver protein $(\mathrm{g})$ of rats treated with different diets for 6 weeks.

Note: $C_{10}-10.0 \%$ protein (casein), $C_{8} G_{2}-10.0 \%$ protein (8.0\% casein and $2.0 \%$ gelatin), and $C_{10} G_{2.5}-12.5 \%$ protein $(10.0 \%$ casein and $2.5 \%$

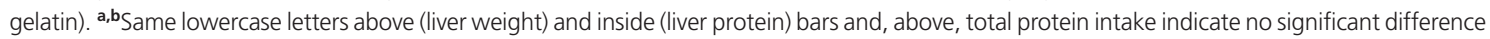
$(p>0.05)$. 
Table 3. Weight gain, food and protein intake, and protein utilization in rats after four weeks of experiment.

\begin{tabular}{|c|c|c|c|c|c|c|c|c|}
\hline \multirow{3}{*}{ Parameter } & \multicolumn{8}{|c|}{ Diet } \\
\hline & \multicolumn{2}{|c|}{$C_{10}$} & \multicolumn{2}{|c|}{$\mathrm{C}_{8} \mathrm{G}_{2}$} & \multicolumn{2}{|c|}{$C_{12.5}$} & \multicolumn{2}{|c|}{$C_{10} G_{2.5}$} \\
\hline & M & SD & M & SD & M & SD & M & SD \\
\hline Weight gain (g) & 114.0 & $15.9^{\mathrm{a}}$ & 99.6 & $14.7^{\mathrm{a}}$ & 106.3 & $16.5^{\mathrm{a}}$ & 187.6 & $16.1^{\mathrm{a}}$ \\
\hline Total energy intake (kcal) & 1467.0 & $145.1^{\mathrm{a}}$ & 1491.6 & $149.8^{\mathrm{a}}$ & 1382.5 & $157.7^{\mathrm{a}}$ & 1296.8 & $160.4^{\mathrm{a}}$ \\
\hline Daily food intake (g) & 13.6 & $1.3^{\mathrm{a}}$ & 13.8 & $1.4^{\mathrm{a}}$ & 12.8 & $1.5^{\mathrm{a}}$ & 12.0 & $1.5^{\mathrm{a}}$ \\
\hline Food intake (\%) & 81.5 & $6.6^{\mathrm{a}}$ & 80.5 & $7.4^{\mathrm{a}}$ & 78.3 & $8.0^{\mathrm{a}}$ & 73.1 & $7.5^{\mathrm{a}}$ \\
\hline Total protein intake (g) & 39.2 & $3.9^{\mathrm{a}}$ & 41.3 & $4.2^{\mathrm{a}}$ & 45.8 & $5.2^{\mathrm{a}}$ & 42.8 & $5.3^{\mathrm{a}}$ \\
\hline FCR & 3.35 & $0.19^{c}$ & 3.91 & $0.34^{\mathrm{a}}$ & 3.39 & $0.28^{b, c}$ & 3.86 & $0.32^{\mathrm{a}, \mathrm{b}}$ \\
\hline PER & 2.90 & $0.17^{\mathrm{a}}$ & 2.41 & $0.22^{\mathbf{b}}$ & 2.32 & $0.19^{b}$ & 2.03 & $0.16^{c}$ \\
\hline RPER & \multicolumn{2}{|c|}{$100.0^{\mathrm{a}}$} & 83.6 & $7.7^{b}$ & \multicolumn{2}{|c|}{$100.0^{\mathrm{a}}$} & 87.7 & $6.9^{\mathbf{b}}$ \\
\hline Corrected PER & \multicolumn{2}{|c|}{$2.50^{\mathrm{a}}$} & 2.08 & $0.19^{b}$ & \multicolumn{2}{|c|}{-} & \multicolumn{2}{|c|}{-} \\
\hline True digestibility (\%) & 95.3 & $1.0^{\mathrm{a}}$ & 94.9 & $0.5^{\mathrm{a}}$ & 94.6 & $1.2^{\mathrm{a}}$ & 94.3 & $0.8^{\mathrm{a}}$ \\
\hline
\end{tabular}

Note: $C_{10}: 10.0 \%$ protein (casein), $C_{8} G_{2}: 10.0 \%$ protein (8.0\% casein and $2.0 \%$ gelatin), $C_{12.5}: 12.5 \%$ protein (casein) and $C_{10} G_{2.5}: 12.5 \%$ protein $(10 \%$ casein and $2.5 \%$ gelatin). Different lowercase letters within a row indicate significant differences $(p<0.05)$. Food intake=[(diet offered - diet rejected)/ diet offered) $\times$ 100].

FCR: Food Conversion Ratio, PER: Protein Efficiency Ratio, RPER: Relative PER; M: Mean; SD: Standard Deviation.

The liver weight $(\mathrm{g})$ and the relative liver weight of the casein/gelatin groups $\left(\mathrm{C}_{8} \mathrm{G}_{2}=3.8 \%\right.$ $\left.\pm 0.2, C_{10} G_{2.5}=3.6 \% \pm 0.4\right)$ were lower than those of the control group $\left(C_{10}=4.2 \% \pm 0.4\right)$; the liver protein ( $\mathrm{g}$ ) of the $\mathrm{C}_{10} \mathrm{G}_{2.5}$ group was lower than that of the $C_{10}$ group $(p<0.05)$, and there were no differences in the protein intake between the three groups of animals (Figure 2). The total liver fat was similar in all of the three groups ( $p>0.05)$, as follows: $C_{10}=0.28 \mathrm{~g} \pm 0.07 ; C_{8} G_{2}=0.28 \mathrm{~g} \pm 0.06$, and $C_{10} G_{2.5}=0.22 \mathrm{~g} \pm 0.02$.

\section{DISCUSSION}

Gelatin has lower contents of all the indispensable amino acids than those considered necessary for human health4; its AAS is zero. On the other hand, some dispensable amino acids (alanine, arginine, glycine, and proline) are present in gelatin in excessive amounts when compared to other proteins of animal origin ${ }^{19-21}$, such as casein (Table 2). This atypical and imbalanced amino acid profile in relation to human protein requirements suggests that gelatin should not be consumed by humans as a primary source of protein $^{4,5}$.

The animals fed only gelatin as protein source lost body weight in a similar way to those fed the protein-free diet, as reported in other studies ${ }^{22,23}$. This result can be explained by the low protein quality of gelatin since its deficiency in indispensable amino acids inhibits endogenous protein synthesis. Furthermore, there is evidence in the literature that rats reject diets deficient in indispensable amino acids. As a result, the food intake of the animals is lower than their energy requirements ${ }^{24}$. This was confirmed in the present study as the $G_{10}$ group rejected more than half $(57.6 \%)$ of the diet offered. The low energy intake along with the deficiency in indispensable amino acids accelerated the protein malnutrition of the animals ${ }^{25}$.

The similar food and energy intake resulted in no differences in the weight gain between the casein and casein/gelatin groups during the four weeks of experiment. Therefore, the different protein sources did not influence the weight gain in the different groups of animals. In addition, the similar energy intake between the treatments did not interfere with the bioavailability of protein sources, as recommended for in vivo protein quality evaluation ${ }^{19,25}$.

Food conversion ratio of the experimental groups was higher than that of the control group, both regarding casein complementation $\left(\mathrm{C}_{8} \mathrm{G}_{2}\right.$ 
versus $\left.C_{10}\right)$ and supplementation $\left(C_{10} G_{2.5}\right.$ versus $C_{10}$ ) with gelatin. Therefore, food efficiency was lower when gelatin was present in the diet, making it necessary a higher intake of the casein/ gelatin diet than the control diet (10\% protein) in order to reach similar weight gain.

The high quality of casein was reduced when it was complemented with gelatin at the two protein levels evaluated $\left(C_{8} G_{2}\right.$ versus $C_{10}$ and $C_{10} G_{2.5}$ versus $\left.C_{12.5}\right)$, as well as when it was supplemented with gelatin $\left(C_{10} G_{2.5}\right.$ versus $\left.C_{10}\right)$. PER is a more sensitive method to evaluate protein quality since it uses growing animals, which have a higher protein requirement than adult animals. Furthermore, the PER index takes longer to complete than other methods, such as Net Protein Ratio (NPR) (28 days versus 10-14 days, respectively). For these reasons, the PER is sensitive to small differences in protein quality ${ }^{19,25,26}$.

The reference protein efficiency ratio of casein is $2.5^{18,25}$, based on the Association of Official Analytical Chemists (AOAC) official method ${ }^{17}$, which does not include supplementation with sulfur-containing amino acids. However, when the AIN-93G diet at $10 \%$ protein is used, the PER value of casein is higher than 2.5, as found in the present study, because the AIN diet is supplemented with L-cystine in order to correct the casein's deficiency in sulfur-containing amino acids $^{12}$. The corrected PER (adjusted to 2.5) of the $\mathrm{C}_{8} \mathrm{G}_{2}$ diet was lower than that of casein $(p<0.05)$ and close to 2.0, which is the minimum requirement for a good quality protein ${ }^{25}$.

The high protein digestibility of the diets (approximately 95\%) indicates that gelatin did not influence casein digestibility. The absorption of the amino acids in gelatin is facilitated since it is a partially-hydrolyzed protein derived from collagen, and its digestibility is comparable to that of casein ${ }^{3,21}$. Therefore, it can be concluded that protein digestibility did not influence the decrease in protein efficiency in the casein/gelatin mixture.

After six weeks of experiment, the total protein intake of the groups was similar, but in the protein supplementation diet $\left(C_{10} G_{2.5}\right)$, the hepatic protein was lower than that of control group. This fact suggests that the additional gelatin decreases the protein retention in the liver, i.e., the protein bioavailability.

Considering that the casein/gelatin mixture (4:1 of protein content) has sufficient indispensable amino acid content, as well as high digestibility, this mixture could be expected to have protein quality close to that of casein. However, this study showed that gelatin negatively influenced the protein quality of the casein/gelatin mixture. One possible explanation for this result could be the high contents of some dispensable amino acids in gelatin, such as glycine. During the protein absorption by the amino acid transport system, glycine (like other amino acids) has affinity for more than one carrier in the intestinal brush border. Therefore, molecules with a similar chemical structure compete for the same carrier ${ }^{26}$. As a result, the absorption of some indispensable amino acids can be impaired due to the excess of dispensable amino acids, which reduces the bioavailability of indispensable amino acid ${ }^{27,28}$. Thus, further investigations are needed on the reduction in protein bioavailability by gelatin when it is mixed with a high-quality protein, for example, performing a fecal amino acid profile analysis. We also suggest further investigation on the influence of gelatin on malnutrition recovery in different protein mixtures since it can be used to induce experimental malnutrition ${ }^{29}$.

In the present study, using casein and gelatin mixtures of ( $20 \%$ of the protein content), it was observed that gelatin decreases the efficiency of a high-quality protein in proteinrestricted diets. This finding suggests that in some clinical practices, mainly in situations that involve protein catabolism, gelatin, or partially-hydrolyzed collagen could eventually worsen the catabolic status and thus slow patient recovery. Moreover, in cases of high rate of catabolism, such as major burns, cancer, and malnutrition, special attention to the supplements prescription is suggested because these products can have gelatin as source of protein or amino acids. 


\section{CONCLUSION}

Gelatin interferes with protein efficiency of high-quality protein. This influence depends on the gelatin concentration in the mixtures and the amount of protein in the diet. When there is low protein intake, gelatin decreases food efficiency and the bioavailability of high-quality protein.

\section{ACKNOWLEDGEMENTS}

The authors are grateful for the financial support provided by the Conselho Nacional de Desenvolvimento Científico e Tecnológico (research scholarship) and to the Professors Alceu Afonso Jordão Júnior and Daniela Canuto Fernandes for theoretical support.

\section{CONTRIBUTORS}

CCD BORDIN was responsible for data collection, literature review, and manuscript writing. MMV NAVES was responsible for the research design (idea and planning), participated in data analysis and synthesis, and contributed to the drafting and critical revision of the manuscript.

\section{REFERENCES}

1. Prestes RC, Golunski SM, Toniazzo G, Kempka AP, Luccio MD. Caracterização da fibra de colágeno, gelatina e colágeno hidrolisado. Rev Bras Prod Agroind. 2013; 15(4):375-82.

2. Poppe J. Gelatin. In: Imeson A. Thickening and gelling agents for food. $2^{\text {nd }}$ ed. London: Blackie Academic and Professional; 1997. p.144-68.

3. Djagny KB, Wang Z, Xu S. Gelatin: A valuable protein for food and pharmaceutical industries: Review. Crit Rev Food Sci Nutr. 2001; 41(6):481-92. http://dx.doi.org/10.1080/20014091091904

4. Institute of Medicine. Protein and amino acids. In: Dietary references intakes for energy, carbohydrate, fiber, fat, fatty acids, cholesterol, protein, and amino acids. Washington (DC): The National Academies; 2005. p.589-768.

5. Moskowitz RW. Role of collagen hydrolysate in bone and joint disease. Semin Arthritis Rheum. 2000; 30(2):87-99. http://dx.doi.org/10.1053/sarh. 2000.9622
6. Ten Have GA, Engelen MP, Soeters PB, Deutz NE. Absence of post-prandial gut anabolism after intake of a low quality protein meal. Clin Nutr. 2012; 31(2):273-82. http://dx.doi.org/10.1016/j.clnu. 2011.09.008

7. Proksch E, Segger D, Degwert J,Schunck M, Zaque V, Oesser S. Oral supplementation of specific collagen peptides has beneficial effects on human skin physiology: A doubleblind, placebo-controlled study. Skin Pharmacol Physiol. 2014; 27(1):47-55. http://dx.doi.org/10.1159/000351376

8. Shimizu J, Asami N, Kataoka A, Sugihara F, Inoue $\mathrm{N}$, Kimira Y, et al. Oral collagen-derived dipeptides, prolyl-hydroxyproline and hydroxyprolyl-glycine, ameliorate skin barrier dysfunction and alter gene expression profiles in the skin. Biochem Biophys Res Commun. 2015; 456(2):626-30. http://dx.doi. org/10.1016/j.bbrc.2014.12.006

9. Hochstenbach-Waelen A, Westerterp-Plantenga MS, Veldhorst MA, Westerterp KR. Single-Protein casein and gelatin diets affect energy expenditure similarly but substrate balance and appetite differently in adults. J Nutr. 2009; 139(12):2285-92. http://dx.doi.org/10.3945/jn.109.110403

10. Veldhorst MA, Nieuwenhuizen AG, HochstenbachWaelen A, Westerterp KR, Engelen MP, Brummer $\mathrm{RJ}$, et al. A breakfast with alpha-lactalbumin, gelatin, or gelatin + TRP lowers energy intake at lunch compared with a breakfast with casein, soy, whey, or whey-GMP. Clin Nutr. 2009; 28(2):147-55. http://dx.doi.org/10.1016/j.clnu.2008.12.003

11. Brylinsky C. Overview of nutrition diagnosis and intervention. In: Mahan LK, Escott-Stump S, Raymond $J$ L. Krause's food, nutrition and diet therapy. $13^{\text {th }}$ ed. Philadelphia: WB Saunders Company; 2011. p.253-73.

12. Mackay D, Miller AL. Nutritional support for wound healing. Altern Med Rev. 2003; 8(4):359-77.

13. National Research Council. Guide for the care and use of laboratory animals. $8^{\text {th }}$ ed. Washington (DC): National Academy Press; 2011.

14. Reeves PG, Nielsen FH, Fahey Jr. GC. AIN-93 purified diets for laboratory rodents: Final report of the American Institute of Nutrition ad hoc Writing Committee on the Reformulation of the AIN-76A rodent diet. J Nutr. 1993; 123(11):1939-51.

15. Merril AL, Watt BK. Energy value of foods: Basis and derivation. Agriculture Handbook, $n^{\circ} 74$. Washington (DC): United States Department of Agriculture; 1973.

16. Bidlingmeyer BA, Cohen SA, Tarvin TL. Rapid analysis of amino acids using pre-column derivatization. J Chromatogr. 1984; 336(1):93-104. http://dx.doi. org/10.1016/S0378-4347(00)85133-6 
17. Association of Official Analytical Chemists International. Official methods of analysis. $19^{\text {th }} \mathrm{ed}$. Arlington: AOAC; 2012.

18. Bligh EG, Dyer WJ. A rapid method of total lipid extraction and purification. Can J Biochem Physiol. 1959; 37(8):911-7. http://dx.doi.org/10.1139/o59-0 99

19. Pellett PL, Young VR. Nutritional evaluation of protein foods. Tokyo: The United Nations University; 1980.

20. Food and Agriculture Organization. Protein and amino acid requirements in human nutrition. Geneva: WHO; 2007. Technical Report Series, n 935.

21. Rutherfurd SM, Montoya CA, Moughan PJ. Effect of oxidation of dietary proteins with performic acid on true ileal amino acid digestibility as determined in the growing rat. J Agric Food Chem. 2014; 62(3):699-707. http://dx.doi.org/10.1021/j4403 $146 \mathrm{u}$

22. Castro IA, Tirapegui J, Silva RS. Protein mixtures and their nutritional properties optimized by response surface methodology. Nutr Res. 2000; 20(9):1341-53. http://dx.doi.org/10.1016/s0271-5 317(00)00209-8

23. Naves MMV, Ferreira CC, Freitas CS, Silva MS. Avaliação da qualidade proteica de dois suplementos alimentares em ratos Wistar. Aliment Nutr. 2006; 17(1):35-42.

24. Gietzen DW, Hao S, Anthony TG. Mechanisms of food intake repression in indispensable amino acid deficiency. Annu Rev Nutr. 2007; 27(1):63-78. doi: 10.1146/annurev.nutr.27.061406.093726

25. Friedman M. Nutritional value of proteins from different food sources: A review. J Agric Food Chem. 1996; 44(1):6-29. http://dx. doi.org/10.1021/jf9 400167

26. Brody T. Protein. In: Brody T. Nutritional biochemistry. $2^{\text {th }}$ ed. San Diego: Academic Press; 1998.

27. Matthews DM, Adibi SA. Peptide absorption. Gastroenterology. 1976; 71(1):151-61.

28. Silk DB, Grimble GK, Rees RG. Protein digestion and amino acid and peptide absorption. Proc Nutr Soc. 1985; 44(1):63-72.

29. Leite SN, Andrade TAM, Frade MAC, Jordão Júnior AA, Masson DS. Modelos experimentais de desnutrição e sua influência no trofismo cutâneo. An Bras Dermatol. 2011; 86(4):681-8.

Received: July 16, 2014

Final version: April 29, 2015

Approved: May 22, 2015 